\title{
DE KOLONIE CURAÇAO ONDER ENGELSCH BESTUUR VAN 1807 TOT 1816
}

DOOR

\author{
B. DE GAAY FORTMAN
}

Er is maar weinig bekend van de geschiedenis van Curaçao, Aruba en Bonaire in het tijdvak van het tweede Engelsche bestuur. Euwens schreef in De West-Indische Gids 1924/5 over „De eerste dagen van het Engelsche bewind op Curaçao in 1807" (blz. 575-581), nadat hij tevoren (blz. 461-464) een afschrift had gegeven van de oorkonde der aanstelling van sir James Cockburn tot gouverneur, gedagteekend 12 Mei 1807. Beide opstellen zijn ontleend aan stukken, destijds aanwezig in het koloniaal archief van Curaçao, thans onder de nrs. 455 (minuut-notulen van de vergadering van den Raad van politie in 1807) en 1513 te vinden in het Oud-archief van Curaçao en onderhoorige eilanden Bonaire en Aruba op het Algemeen rijksarchief te 's-Gravenhage.

De Encyclopaedie van Nederlandsch West-Indië geeft op bladz. 328 niet geheel juist de namen der Engelsche bestuurders, en vat op blz. 257 de geschiedenis van dezen tijd aldus samen: ,,... reeds in 1807 veroverden de Engelschen zonder veel moeite het eiland opnieuw. Nu werd de ellende nog grooter: de Engelschen veroverden Guadeloupe en begonnen openlijk te handelen met de Spaansche koloniën in Amerika, waardoor Curaçao als tusschenstation overbodig werd; het toppunt van ellende werd bereikt tijdens den Engelsch-Amerikaanschen oorlog (1812-1814)".

Ds. Bosch weet nog te verhalen, dat door ruime verteringen van het talrijke garnizoen en door de onbekrompen en gezellige levenswijze van vele Engelsche ambtenaren en kooplieden de inwoners van Curaçao hun achteruitgang minder gevoelden. Er werd veel geld weggehaald en naar Jamaica gebracht; 's lands gebouwen en slaven werden verkocht en vele nieuwe belastingen opgelegd. De 
gelden van de Kaapvaartkas en van de Weeskamer werden door een beroep op den Engelschen koning gered (Reizen in West-Indië en door een gedeelte van Zuid-en Noord-Amerika I, blz. 365367).

Hetgeen zich in het Oud-archief van Curaçao bevindt, voor de algemeene geschiedbeschrijving van de kolonie van belang, stelt niet in staat tot het geven van een volledig overzicht ${ }^{1}$ ). Over Bonaire en Aruba ontbreken nagenoeg alle gegevens. Naast de zoo juist genoemde notulen van de vergadering van den Politieken raad (1807-1816) zijn het belangrijkst de publicatiën van den gouverneur, al en niet in rade, onderscheidenlijk onder de nrs. 455-464 en 522-530 beschreven. Waarschijnlijk winnen de publicatiën het in belangrijkheid van de notulen, omdat zij vrij uitvoerig de beweegredenen, waaraan zij haar ontstaan te danken hebben, laten voorafgaan. De notulen bevatten voor het grootste deel beschikkingen op verzoekschriften, welke in den regel niet meer inhouden dan een omschrijving van datgene, wat op den kant als samenvatting met ,,granted” of ,rejected” even duidelijk is aangegeven.

De veroveraar van Curaçao, Charles Brisbane, was ook de eerste nieuwe gouverneur. Gelijk bekend is, vertrok hij kort na de verovering naar Jamaica, in welken tijd William Bolton, de bevelhebber van de Fisgard het bestuur waarnam, maar 27 Januari was hij terug en deed hij mededeeling van zijn optreden als gouverneur in afwachting van een benoeming door den Engelschen koning. Toch was hij in dien tijd nog veel afwezig, en dan traden als luitenant-gouverneurs tot zijn vervanging op behalve Bolton achtereenvolgens David Baillie, die eerst als boekhouder-generaal en uit dien hoofde lid van den Raad van politie voorkomt, Micaiah Malbon (in 1807), Robert Nicholas (1808).

Sir James Cockburn baronet was de opvolger van Brisbane. Hij vertoefde op Curaçao van 9 Juni 1808-20 Mei 1809. Na hem was de brigadier-majoor John Thomas Layard, commandant van de Engelsche krijgsmacht op Curaçao, tot 18 Juni 1811 als luitenantgouverneur met het bestuur belast. Als deze in de vergadering op den laatstgenoemden dag de benoeming van den majoor-generaal John Hodgson tot gouverneur meedeelt, voegt hij daaraan toe,

1) In een catalogus van den antiquarischen boekhandel van Francis Edwards te Londen van 1927 vindt men een achttal nummers uit den tijd van den gouverneur Hodgson: militaire brieven en documenten, betrekking hebbende op het bestuur van Curaçao, op de aanraking met de Spaansche koloniën in Zuid-Amerika en den oorlog met Amerika. 
dat deze de opvolger van Cockburn is. Tot 15 September 1814 stond Hodgson aan het hoofd der kolonie; op dien dag vertrok hij naar Europa, na het bestuur overgedragen te hebben aan den majoor-generaal John Lecouteur, Layards opvolger als commandant der troepen. Hij was de laatste Engelsche gouverneur, en droeg 4 Maart 1816 de kolonie over aan den Nederlandsche gouverneur-generaal Albert Kikkert.

Een der laatste bestuursdaden van den gouverneur Changuion (1804-1807) was geweest de formeele scheiding van de politieke en justitieele macht door instelling van een Raad van civiele en crimineele justitie met mr. P. B. van Starckenborgh als voorzitter. Als fiskaal was deze opgevolgd door mr. B. Blok. Bij gebreke van geschikte ingezetenen voor het rechtersambt had de gouverneur echter voorloopig leden van den Raad van politie in dien van justitie benoemd ${ }^{1}$ ).

De Engelschen lieten tot 2 Juni 1807 dezen Raad van justitie als afzonderlijk college bestaan, maar benoemden daarin de commissarissen voor mindere questiën en geschillen als leden. Daarna werd het weer als vóór December 1806: één Raad van politie en van civiele en crimineele justitie, die echter van zijn zittingen als Raad van justitie afzonderlijke notulen hield.

De notulen van den Raad van politie werden in het Engelsch gehouden; aanvankelijk volgde geregeld een Nederlandsche vertaling, daarna ongeregeld en na 18 October 1808 in het geheel niet meer. In hun schriftelijke gedachtenwisseling bedienden de meeste leden zich van het Nederlandsch, waarvan dan door den gouvernementstolk ten gerieve van de Engelsche leden een vertaling gemaakt werd. Vooral Van Starckenborgh schreef zijn meermalen nogal uitvoerige adviezen in zijn moedertaal.

Met Changuion had aanstonds een zevental ambtenaren geweigerd in Engelschen dienst over te gaan. Toen in een bespreking met de leden van den Raad van politie op 21 Januari 1807 Bolton de vraag stelde, of men genegen was zijn ambt als raadslid te blijven uitoefenen, antwoordden Berch, Beutner en Cancrijn bevestigend. De boekhouder-generaal C. E. van Eck ${ }^{2}$ ) gaf een eigen-

1) Zie „Curaçao en onderhoorige eilanden Bonaire en Aruba van 1804 tot 1806. Het bestuur van den gouverneur J. P. Changuion" in D.W.I.G. 1943 blz. 22.

2) Christiaan Emilius van Eck, geboren te Sluis, komt reeds in 1796 voor als raad en ad interim boekhouder-generaal op een traktement 
aardig antwoord, dat hierop neerkomt, dat hij ook wel graag zou willen, maar nu eenmaal in Holland had laten weten, dat hij ,,van alle ambten en waardigheden zou desisteeren", en daarom wel verplicht was te bedanken. Er moest dus een nieuwe boekhoudergeneraal zijn en daartoe werd een Engelschman benoemd, de reeds genoemde D. Baillie, die eerst als secretaris voorkomt, en in die hoedanigheid op zijn verzoek Willem Prince als zijn ,,deputy" zag aangewezen. Als boekhouder-generaal werd Baillie nog in 1807 opgevolgd door J. J. Vidal, die op zijn beurt plaats maakte voor Charles Baggs, tevens vendu-meester, terwijl in $1808 \mathrm{Ja}^{\mathrm{s}}$ Christie en in $1811 \mathrm{H}$. Chapman als boekhouder-generaal optrad. Vidal is ook gouvernementssecretaris geweest, en na hem waren dat John Elliot, die ook als ontvanger-generaal voorkomt, in 1810 Colonel John Robertson, in 1811 J. G. P. Tucker.

Op denzelfden dag, waarop Bolton de leden van den Raad van politie voor de vraag stelde, of zij onder het Engelsch bewind hun ambt wilden blijven bekleeden, had Van Starckenborgh daarover een bespreking met de commissarissen van mindere questiën en geschillen. Allen beantwoordden de vraag, of zij met de leden van den Raad van politie wilden samenwerken als Raad van justitie, bevestigend. Het waren Theodorus Jutting, Frans Rojer, David Barkmeijer, Lourens de Meij Crisson.

Den 27sten Januari 1807 had onder voorzitterschap van Bolton de eerste vergadering van den Raad van politie plaats. Van Starckenborgh hield een toespraak tot den voorzitter, die deze rede beantwoordde en zijn vredelievende bedoelingen, in zijn door Changuion afgewezen sommatie van 22 December 1806 reeds tot uiting gebracht, herhaalde ${ }^{1}$ ).

Wat de werkzaamheden van den raad betreft, heeft men te onderscheiden tusschen het overleg met den gouverneur over allerlei onderwerpen, den toestand van het eiland betreffende, zijn

van 5000 gulden. Blijkbaar heeft hij ook op Bonaire dienst gedaan, want in 1806 werd hij door den gouverneur geraadpleegd als deskundige in de Indianen-kwestie, die zich daar voordeed (D. W. I. G. 1942, blz. 254). In de stukken van de Hooge militaire vierschaar over de gebeurtenis van 1 Jan. 1807 wordt hij genoemd ,,een Eerlijk en goed Boekhouder doch geborneerd Mensch, zoon van een gewezen koetzier". In de notulen van den Raad van politie komt een verzoekschrift voor van zijn op Curaçao wonende weduwe Dorothea Maria Swart, die zelf 29 Aug. 1842 overleed, nalatende een dochter A. C. van Eck (Gouv. journaal 31 Aug. en 24 Sept. 1842).

1) Zie Euwens D. W. I. G. 1924/5 blz. 578. 
raadgevende taak, de beschikking op allerlei verzoekschriften, meest van familierechtelijken aard, ofschoon ook herhaaldelijk beschikkingen in andere rechtsverhoudingen voorkomen, en ten slotte zijn verordenende taak samen met den gouverneur. Wat dezen laatste betreft, blijkt niet duidelijk waar de bevoegdheid van den gouverneur om alleen te beslissen ophield. Als veroveraar ging van Brisbane op 12 Januari 1807 een publicatie uit, waarbij allen, die eigendommen van onderdanen van landen, die met Engeland in oorlog waren, onder zich hadden of zouden krijgen, opgeroepen werden deze in te leveren. Van denzelfden aard was de publicatie, waarbij herinnerd werd aan de capitulatie-voorwaarden betreffende de inlevering van wapenen en den eed van trouw aan den Engelschen koning.

In de vergadering van den 27sten Januari 1807 werd besproken de geldelijke toestand van het eiland. Daarbij blijkt het, dat de gouverneur een jaarwedde van 10000 pesos ${ }^{1}$ ) zou genieten. De fiskaal, die hem het meest nabij kwam, ontving als zoodanig 4000 en als vice-president van den raad van justitie 3000 pesos. Als inkomsten worden genoemd: recognitiegelden, hoofd- en familiegelden (t.w. 4 realen hoofdgeld voor iederen slaaf van 16 tot 60 jaar, en familiegeld in 3 klassen van 7,4 en 2 pesos), $1 \%$ voor de Kaapvaartkas wegens inkomende rechten en uitgaande rechten van koffie, cacao en katoen, de 50ste penning van alle vaste effecten bij het transporteeren, accijns van alle waren, impost, waaggeld, placaat- en havengeld, penningen der navigeerende vaartuigen, contributies voor de nationale garde, betaling voor manumissies. Herhaaldelijk werden publicatiën uitgegeven, waarbij de ingezetenen werden aangespoord hun belastingen op te brengen; dit geldt in het bijzonder van de hoofd- en familiegelden en de contributies voor de nationale garde.

Over de dronkenschap der soldaten en matrozen en over door hen gepleegde baldadigheden en gewelddadigheden leest men herhaaldelijk klachten. Daarmee zal men in verband moeten brengen het voorschrift van Bolton, dat voor het houden van logement,

1) Tot de zeer weinige tot het Engelsch bestuur behoorende papieren die in het archief achtergebleven zijn, behoort een verzoekschrift van James William Graves acting brigadier-generaal, commandeerende het 2de bataljon Royal Irish Regiment of Foot, en zijn officieren, om ,,colonial pay or an annual allowance" als gebruikelijk, te weten 25000 guilders voor den gouverneur, 12000 voor den generaal of commandeerenden officier, 2600 voor een luitenant-kolonel, 2000 voor de majoors en 24000 voor 40 officieren. 
herberg, taphuis, speelhuis, kroeg e.d. verlof van den gouverneur noodig was, alsook het telkens herhaald verbod om dranken te verkoopen aan militairen van lageren rang. Herhaaldelijk wordt ook gewaarschuwd tegen het verbergen en voorthelpen van deserteurs.

Ds. Bosch deelt in zijn Reizen in West-Indië II, blz. 268 mee, dat in dit jaar onder de Engelsche bezetting en matrozen de gele koorts zoo hevig heerschte, dat er dagen waren, waarop 20 lijken begraven moesten worden. Ook de raadsnotulen spreken van groote sterfte.

Maar evenzeer waren maatregelen noodig tegen ongeregeldheden van de zijde der bevolking. Zoo mochten negers (vrije en onvrije) des avonds niet zonder lantaarn op straat; deze maatregel gold ook voor mulatten. Belooningen werden uitgeloofd voor de aanbrenging van plegers van ernstige feiten. In Mei 1807 was een matroos van de Latona Richard Sampson vermoord. Of de uitloving van een aanbrengpremie van 500 pesos succes heeft gehad, verneemt men niet. Ook particulieren brachten geld bijeen ten dienste van de opsporing van misdadigers, zoo in dezelfde maand, toen er brand was gesticht op de plantage Vreugdendal van Richard Bateman Lloyd. Zij waren goedgeefscher dan het gouvernement en stelden 600 pesos beschikbaar. Ook in latere jaren komt men dergelijke uitlovingen van premies, alsmede verboden van hulpverleening aan misdadigers, tegen.

Een van de eerste maatregelen van gouverneur en raden was een bepaling tegen woeker: de rente op hypotheken werd bepaald op $6 \%$ ten hoogste 's jaars en die op obligatiën of ,,pand der minne" op $1 \%$ 's maands.

Omstreeks half 1807 ziet men een aantal nieuwe raadsleden optreden: Cornelis Ringeling, Matthias Schotborgh Gz. en ds. P. J. van Esch. Deze laatste hield in de vergadering van 8 Juni 1807 zijn hoogdravende, pro-Engelsche, rede, door Euwens meegedeeld ${ }^{1}$ ), en hij had aanleiding om dankbaar te zijn, want zijn traktement was aanzienlijk verhoogd, wat hem onder Changuion geweigerd was.

1) Over ds. Van Esch D. W. I. G. 1943 blz. 255. Het verzoekschrift van den kerkeraad der ,Nederduitsche hervormde Gemeente”, waarin met een beroep op de roeping naar St. Kruis de traktementsverhooging werd aangevraagd, is mede geteekend door den koster Lucas Hansz. Leden van den kerkeraad waren Frans Rojer en Matthias Schotborgh, ouderlingen, G. J. Siedrechtsz, Pieter Demey, Waters Forbes en Bs. $\mathrm{H}$ k. Kegel, diaconen. 
In de vergadering van 25 November 1807 deelde de gouverneur mee, dat hij tot stijving van 's lands geldmiddelen de belasting op het houden van herbergen met $1 / 3$ had verhoogd en twee nieuwe belastingen had ingevoerd, een op biljardtafels van 2 dollars per maand per tafel en een op speelkaarten van 2 realen per spel.

Tevens werd vastgelegd - een oude kwestie, die na de afschaffing der slavernij nog zooveel stof zou opwerpen - dat de planters hun recht op de publieke weidegronden als te voren zouden behouden, en een planter, die niet zorgde, dat zijn plantage behoorlijk met trankeeren was afgesloten, zou geen vergoeding krijgen voor de schade, hem toegebracht door de beestialen, die op de publieke weiden graasden ${ }^{\mathbf{1}}$ ).

Twee maatregelen in verband met de schaarschte der levensmiddelen in dit eerste jaar moeten nog vermeld worden. Den 10den Februari werd voor zes maanden toegestaan de invoer van timmerhout, levensmiddelen en provisiën met schepen uit alle landen, die met Engeland in vriendschap leefden, en 21 Juni werd ter voorkoming van prijsopdrijving voor de Fransche mais een prijs gezet van 3 pesos per schepel, voor wit meel een van 12 en voor roggemeel een van 9 patienjes het vat, voor rund-, kalfs- en varkensvleesch een van 12 stuivers het pond.

Merkwaardig is het, dat geen der geschiedschrijvers van $\mathrm{Cu}$ raçao iets vermeldt van den orkaan van 17 October 1807. Ds Van Dissel verhaalt wel in zijn „,De hervormde, thans Vereenigde Protestantsche gemeente van Curaçao" (Kerkhistorisch Archief II, blz. 300), dat er tot 1848 in October een dank- en bededag gehouden werd ,na het eindigen van den dusgenoemden orkaanstijd", maar hij vindt dat blijkbaar overbodig, omdat Curaçao van de orkanen, die tusschen Augustus en October soms wel in de tropische gewesten voorkomen, volstrekt geen hinder heeft. Dat deze dank- en bededag zijn oorsprong dankte aan een orkaan, waarvan Curaçao wèl hinder heeft gehad, zooals het ook later nog wel hinder van orkanen zou hebben $(1877,1932)$, was Van Dissel derhalve niet bekend. Bijzonderheden over dezen orkaan heb ik alleen gevonden in een proclamatie van den gouverneur van 29 October 1807, welke aldus begint:

1) 6 Jan. 1809 werd bepaald, dat alle koopbrieven en vergunningen van weiderecht , ten fine van Examinatie" ter secretarie zouden moeten worden ingeleverd. Wie daaraan niet voldeed werd geacht geen weiderecht te hebben. 


\begin{abstract}
„Daar het den Almagtige God, Verheven Schepper en Rechter van Hemel en Aarde behaagt heeft, de Inwoneren van dit Eiland tot Straf hunner Menigvuldige Misdrijven en Boze handelingen, tegen Zijne Goddelijke Majesteit gepleegt, op den $17 \mathrm{n}$ dezer Maand October met eene allerverschrikkelijkste storm te bezoeken, waardoor niet alleen de woningen van verscheide Inwoneren zijn vernield, maar dan ook nog eenige Menschen daarbij het Leeven hebben verloren, hebbende deze gedugte oordeel tevens ziekte en sterfte tengevolge gehad....."
\end{abstract}

Naar aanleiding daarvan werd de 11 de November 1807 en vervolgens de $17 \mathrm{de}$ October van elk jaar tot een ,verjaar-, vast- en verootmoedigingsdag" ingesteld. Ieder zou dan ter kerke moeten gaan; de predikanten zouden toepasselijke predikatiën moeten houden; winkels en kroegen zouden gesloten zijn. Den 6den November werd de eerste dank-, vast- en bededag verschoven van

1 November tot 2 December, en verder verneemt men niets van deze zaak.

In het begin van het volgend jaar (1808) deed zich een kwestie voor met het raadslid Schotborgh, die de gouverneur zeer hoog opnam. Heel duidelijk is de zaak niet, maar zij komt hierop neer, dat Schotborgh de opperhoorigheid van de Engelsche regeering boven den Raad van politie had ontkend. Niet alleen werd hij afgezet en vervangen door den Engelschen secretary John Corser, maar de gouverneur vond in het gebeurde aanleiding den raadsleden een nieuwen eed af te vragen, waarvan de Hollandsche vertaling luidde: „Ik, N.N., zweer, dat ik de verdoemlijke Leer en Stelling, dat Prinsen, welke door den Paap ofte Eenige gezag in de Roomsche zeeën ${ }^{1}$ ) geëxcommuniceerd of in den Ban verklaard zijn, door hare onderdanen ofte Eenige anderen afgezet of vermoord mogen worden, in het Diepste mijner Harte Haat, Verfoeij en Afzweer, en wijders verklaar ik, dat geen Prins, Prelaat, Staat nogte Mogendheid dan alleen onzen Souverein, Heer en koning George ofte Zijner Majesteits opvolgeren Eenige Jurisdictie, Macht, overheid, voorrecht, gezach, 't zij kerkelijk, Geestelijk ofte Tijdelijk, in en over dit Eiland ofte over Eenige andere Zijner Majesteits Domeinen heeft."

Aan zijn uiteenzetting van de zaak in den raad voegde de gouverneur toe, dat ieder, die stellingen als Schotborgh zou huldigen, van de voorrechten der capitulatie zou zijn uitgesloten, verban-

1) Zoo vertaalde de blijkbaar de Nederlandsche taal niet bijster meester zijnde overzetter ,, any Authority o the Seef of Rome", wat beteekent: eenige overheid binnen het rechtsgebied van Rome. 
nen worden, en zijn goederen zouden worden verbeurdverklaard ${ }^{1}$ )

Omdat het bij deze gelegenheid bleek, dat de leden van den raad zijn besluiten niet geheim hadden gehouden, werd thans uitdrukkelijk geheimhouding opgelegd.

Brisbane had bepaald, dat verzoekschriften aan den raad in het Engelsch moesten worden gesteld of van een Engelsche vertaling voorzien. Cockburn kwam met een veel verder strekkend besluit. Hadden de Engelsche leden van den raad zich verontschuldigd van de zittingen van den raad van justitie, omdat zij de Hollandsche taal niet machtig waren, 27 Augustus 1808 stelde gouverneur vast, dat ,naardien deze Colonie thans Effectivelijk eene Engelsche Colonie geworden is"' alle stukken aan de rechtbanken alleen in het Engelsch zouden kunnen gesteld worden.

Van dezen gouverneur zijn voorts eenige maatregelen op procesrechtelijk gebied, die niet van veel belang zijn. Van hooger hand werd bepaald, dat beroep op den koning in zijn raad zou bestaan in zaken boven 500 pond sterling.

Voorts werd een zegelbelasting ingevoerd, die herhaaldelijk wijziging onderging.

Van Cockburn is een nieuwe indeeling van het eiland Curaçao in drie divisiën onder landdrosten, die ook recht zouden doen in geringe kwesties en verschillen, onderverdeeld in divisiën. In de oostdivisie werd landdrost Johannes Brands, in de west-divisie Frans Rojer en in de middeldivisie Gerardus Duyckinck. Districtmeesters waren Claas Schotborgh, Alexander Evertsz en Daniel Specht, Carel van der Meulen, Matthias Schotborgh Jz. en Jan van der Linden, Constantinus Schotborgh en David Gaerste.

Beoosten de Willemstad (,Williamtown" 2) bevond zich aan den zeekant tusschen de batterijen Halvemaen en Krommelijn het Protestantsche kerkhof. Reeds vele jaren waren er klachten over ontwijding van deze plaats: men liet er vee loopen en gebruikte het tevens als slachtplaats. Daaraan en aan de schennis der graven zelf zal in dezen tijd te wijten zijn de klacht in de

$\left.{ }^{1}\right)$ Is Schotborgh later weer in gunst aangenomen? In $1810 \mathrm{komt}$ Matts. Schotborgh Gz. voor als vendumeester.

$\left.{ }^{2}\right)$ In een publicatie van 24 Jan. 1807 wordt een bevel om de lichten in de stad om 10 uur uit te doen aldus gemotiveerd: ,Naardien de Stad Amsterdam, anders Willemstad genaamt, gefortificeert en verknogt is aan de citadel of het kasteel", en in een publicatie van $10 \mathrm{Febr}$. 1807 wordt van „,de Haaven van Amsterdam” gesproken. Brisbane vera nderde den naam van fort Republiek in George.

Het ,God save the King" onder de publicatiën vertaalde men eerst in , ,Lang leve de koning”, later in „,God spare den koning”. 
notulen van den raad, dat het kerkhof veel stank verspreidde. Het lag in de onmiddellijke nabijheid van het fort Amsterdam, en werd nadeelig voor de gezondheid van het garnizoen geacht. Cockburn liet het sluiten, en stelde zich voor, dat uit vrijwillige bijdragen de kosten van een nieuwe begraafplaats zouden gevonden worden, maar het liep niet hard, en daarom werd tot een hoofdelijken omslag voor dit doel besloten, waarna de zaak haar beslag kreeg.

Over het algemeen was er weinig bereidheid bij de burgerij om vrijwillig te voldoen aan haar opgelegde lasten. De aanmaningen tot betaling van hoofd- en familiegeld moesten telkens herhaald worden. Een oproeping tot de vrije negers en mulatten, gedaan aan hun officieren, om mee te werken aan de herstelling van openbare wegen had geen gevolg vóór met verbeurdverklaring van hun eigendommen gedreigd was. $\mathrm{Bij}$ een andere gelegenheid, toen slaven beschikbaar moesten gesteld worden voor andere openbare werken, zond men kinderen, ouden en gebrekkigen.

De voedselvoorziening baarde telkens weer zorg. In Februari 1808 werd eerst nog ter aanmoediging van den vrijen en onbelemmerden aanvoer van levensmiddelen en ter bevordering van den handel ingetrokken de prijszetting voor meel, mais en versch vleesch, maar telkens ging men toch tot inventarisatie van de aanwezige voorraden over. In Mei kwam er een verbod van inlading van provisiën en water aan boord van schepen, en tegelijkertijd werd voor 6 maanden den aanvoer met Spaansche schepen van bepaalde provisiën toegestaan. Een maand te voren was alle uitvoer van vleesch, spek, boter, meel, mais, kaarsen en andere provisiën verboden; de tegenwoordige staat van zaken tusschen Engeland en de Vereenigde staten van Amerika werd daarbij genoemd als schaarschheid van levensmiddelen doende verwachten. Nijpend was de nood nog niet, want einde Juni werd die uitvoer, mits naar andere Engelsche koloniën, reeds weder toegestaan, wanneer op Curaçao geen koopers tegen bepaalde prijzen te vinden waren.

Op het gebied van den handel werden nieuwe bepalingen gemaakt, waarbij Curaçao weinig zijde spon. Toen het uitlekte, dat men via Aruba, waar waarschijnlijk minder toezicht was, met de Spaansche kust en Jamaica trachtte handel te drijven, werd alle handel met Aruba verboden. Uitdrukkelijke ontheffing van dit verbod was noodig, toen dit eiland gebrek aan meel kreeg; 6 vaten mochten er in Augustus 1808 heen gezonden worden.

In Maart was een koninklijk besluit van 14 October 1807 afge- 
kondigd, waarbij van Curaçao uit, mits met Engelsche schepen, de handel met de niet door Spanjaarden of Franschen bezette havens en plaatsen op Haïti werd toegestaan, een besluit, dat 11 April gevolgd werd door een ander van den Koning in rade, waarbij voorgeschreven werd om neutrale schepen met hout en provisiën naar de Engelsche koloniën in West-Indië niet te belemmeren, en door een, waarbij de haven van Amsterdam op Curaçao een vrije haven gemaakt werd, te vergelijken met de haven van St. Jozef op Trinidad.

Toen de vrede tusschen Engeland en Spanje gesloten was, trok Engeland daaruit gevolgtrekkingen voor de verhouding tusschen zijn West-Indische koloniën en de Spaansche. Alle onderdanen en vaartuigen der Spaansche ,domeinen” zouden op de vriendelijksten voet in de haven van Curaçao moeten worden ontvangen. De luitenant-kolonel Robertson werd naar Caracas gezonden om besprekingen in het belang van den handel te voeren, en het gelukte ook een verklaring te verkrijgen, die in afwachting van de beschikkingen in het moederland daarover, de in- en uitvoerrechten verlaagde ${ }^{1}$ ).

Een der maatregelen, die genomen werden om in het tekort aan geldmiddelen te voorzien, was de verhuring van de landsslaven op Bonaire en de jaarlijksche verpachting van de rechten op hout kappen, kalk branden, zout inzamelen en vee weiden op dat eiland.

Telkens weer bleek, dat er op Curaçao nog menschen waren, die den eed van trouw aan den Engelschen koning niet afgelegd hadden. Onder hen waren er, die van elders zich op het eiland hadden gevestigd, vooral van Sint Thomas, en daarvoor was tevens verlof noodig, als men ten minste niet uit Engeland kwam, en verplichte inschrijving bij een der burgercompagnieën.

De deserteurs baarden het Engelsche gouvernement veel moeilijkheden. Zij werden door de bevolking verborgen gehouden of vertrokken met in de haven liggende schepen. Eenige malen werd daarom een embargo op alle schepen gelegd. Het bleek, dat de strafbedreiging tegen deze hulpverleening niet voldoende gevolg had, en daarom besloot de gouverneur op het einde van 1808 wel

1) Dit geschiedde in het najaar van 1808. Merkwaardig is, dat een dergelijke gebeurtenis, een overeenkomst met de Venezolaansche overheid na een bezoek van Robertson zich twee jaar later voordeed. In de publicatie van 15 Sept. 1810 werd tegenover de verlaging der rechten in de Spaansche koloniën de uitvoer van daar in Curaçao met Spaansche schepen toegestaan. 
tot een zeer krasse maatregel, nl. dat voor elken deserteur, die niet binnen 60 uur zou zijn gevat, twee inwoners genomen zouden worden.

Op allerlei wijze ging men voort met wettelijke voorschriften niet na te leven. Aan de rechten, verschuldigd voor de vrijlating van slaven, trachtte men te ontkomen door onderhandsche vrijlatingen, die daarop ongeldig verklaard werden.

Een gevolg van de afschaffing door Engeland van den slavenhandel (uit- en invoer in zijn koloniën) was het verbod van uitvoer van slaven, tenzij onder waarborgen voor hun terugkeer.

De eerste moeilijkheid op het gebied van het muntwezen is die, waaraan de vaststelling van de waarde der quadruppels op 16 patientje een einde trachtte te maken. Het zou blijken nog maar een begin te zijn geweest.

In dezen tijd viel ook de beslissing over de gelden, die de veroveraars van Curaçao als hun buit beschouwd hadden, van de Eenpercentkaapvaartkas. De koning van Engeland besliste, dat dit geld hem toekwam, en hij schonk het terug aan de kolonie. Bij de afrekening, die intusschen nog eenige jaren op zich liet wachten, werd $€$ 4044.15.8 uitgekeerd, de tegenwaarde van ruim 20.000 pesos van achten, na aftrek van bijna $£ 600$ aan kosten $\left.{ }^{1}\right)$.

De vraag is wel gedaan, of Curaçao zoogenaamde ,roode" slaven gekend heeft. Voor ontkennende beantwoording ligt misschien een aanwijzing in de beslissing, die de Raad van politie 6 April 1909 gaf over den staat van zekere Anna Maria: ,to declare the said Anna Maria.... to be an Indian woman and in consequence thereof also to declare her freeborn together with her offspring."

In het voorjaar van 1809 was er weer gebrek aan levensmiddelen. Een victualieschip met meel, voor Curaçao bestemd, was benedenwinds vervallen. Er werd daarom bepaald, dat behalve voor zieken, met vergunning van den fiskaal, het brood gebakken zou moeten worden voor $3 / 4$ uit wit en voor $1 / 4$ uit maismeel. Een half jaar later was er zulk een gebrek, dat drie Amerikaansche schepen

1) Carel van der Meulen en Matths. Schotborgh Gz., gewezen commissarissen der eenpercentskaapvaartkas gaven 16 Febr. 1807 aan den raad te kennen, dat zij 10 Februari een order hadden ontvangen van de ,Heeren Commissarissen gesteld tot het onderzoek der Goederen en Effecten, welken niet zouden begrepen zijn in de termen der capitulatie met dit eiland" om ,, aan hun .... over te geven .... bij endossement alle zoodanige penningen, effecten, verbanden, papieren, boeken, en alle andere documenten, concerneerende de voorgemelde Een pct. kaapvaardt cassa", en dat zij daaraan hadden voldaan. 
met levensmiddelen bij uitzondering moesten worden toegelaten. Toen de invoer uit de Engelsche koloniën in Noord-Amerika in de West-Indische koloniën belemmering ondervond, moest men op ruimer schaal afwijken van het beginsel, dat invoer slechts van Engelsche koloniën in de West zou mogen plaats vinden, en werden daarin ook onzijdige havens begrepen, maar gehandhaafd werd, dat deze invoer alleen met Engelsche schepen en door Engelsche onderdanen zou mogen geschieden. En in tijden van nood heeft men ook van dezen laatsten eisch meermalen moeten afzien. Het betrof hier den invoer van houtwaren en levensmiddelen met uitzondering van zout vleesch, spek en boter.

Verscheidene Engelsche kooplieden hadden zich op Curaçao gevestigd. Men komt de namen tegen van Robert Eyle, Dumbar en Mc Whiter, John Harrison, Robertson en Belt, Edward Brooke Penny (later handelsagent voor Zulia en Nederlandsch consul te Maracaībo). Een vreemde figuur was Thomas Maxwell. Hij was toegelaten als ,,attorney" en matigde zich rechten aan als ,,counsellor at Law” en ,,advocate”. Hij slaagde er niet in zijn wetenschappelijke aanspraken te bewijzen, waarop hem verboden werd in eenige ambtelijke hoedanigheid voor de rechtbanken der kolonie te verschijnen. Daar hij, toen er nieuwe klachten tegen hem kwamen, weigerde te voldoen aan een opontbod in den Raad van politie om zijn verontschuldigingen aan te bieden, werd hij ondanks zijn verzet opgepakt en voor tien jaar verbannen.

Een maatregel ten bate van de Engelsche koloniën in NoordAmerika was de afschaffing van invoerrecht op visch, vischolie, meel, maismeel en andere granen, producten van Engelsche visscherijen, rechtstreeks aangevoerd met Engelsche schepen.

4 Maart 1809 werden afgeschaft de brieven, waarmee de afgestempelde gouden Johannessen gangbaar waren. $\mathrm{Zij}$ werden overbodig geacht, daar alle Johannessen met 3 enkele gouvernementsstempels en 1 dubbel stempel zonder meer tegen 11 pesos van achten en 2 realen moesten worden aangenomen.

Sinds het vertrek van ds. Van Esch was de gereformeerde kerk op Curaçao herderloos geweest. In 1810 is er sprake van een ds. Peter Will. Van Dissel vermeldt (t.a.p. blz. 387) een brief van hem aan den kerkeraad der gereformeerde kerk op Curaçao, waarin hij schrijft, dat hij door de Engelsche regeering tot predikant van Curaçao benoemd was en te Londen in de Nederduitsch hervormde kerk bevestigd. Hij zou Engelschman geweest zijn, maar eenigszins met de Hollandsche taal op de hoogte en in die taal ook gepreekt hebben. Het oud-archief bevat een publicatie van

West- Indische Gids X XIV 
den gouverneur, dat Pieter Will, predikant der hervormde gemeente en kapellaan van het garnizoen, voortaan elken zondagmorgen in de hervormde kerk in het fort Amsterdam in het Engelsch zou preken. Later is er over zijn garnizoensdienst nog moeite gekomen. In 1814 bleek hij namelijk niet gerechtigd als predikant van de kerk van Engeland op te treden; hij was van Calvinistische overtuiging. Zelf vertelt hij dan, dat hij in 1802 in handen van bisschop Moore te New York de 39 artikelen onderteekend en den eed afgelegd had.

Voor Fransche aanvallen bleef men bevreesd en allerlei maatregelen, waarin ook de ingezetenen betrokken werden, werden genomen om in dat geval op tegenweer bedacht te zijn. Maar de gezindheid om te vechten bleek bij de burgerij niet grooter te zijn geworden, dan zij was onder het Hollandsche bestuur. Toen de gouverneur op 3 April 1810 alle inwoners van 16 tot 50 jaar van Willemstad, Schaarloo, Pietermaai en Overzijde opriep om zich in compagnieën te laten indeelen, gaven velen daaraan geen gevolg, zoodat de oproeping moest worden herhaald onder bedreiging van boeten.

Reeds het begin van 1811 gaf aanleiding tot enkele maatregelen om in de schaarschte van levensmiddelen, van mais met name, te voorzien. Voor groote en kleine mais werd een prijs gezet van 2 patienjes per schepel en 1 schelling(bit) per kan. Echter was er op de vaste kust evenzeer gebrek, zoodat voor dezen prijs geen invoer plaats vond. Daarom werd kort daarop de verkoop van nieuw-ingevoerde mais vrijgelaten. Tevens werd om aan de schaamtelooze monopoliseering, zooals het genoemd wordt, van den verkoop van levensmiddelen een einde te maken, bepaald, dat deze bij invoer aan den luitenant-gouverneur moesten worden aangeboden, voor het geval hij die geheel of voor een deel zou willen koopen. Een andere maatregel, waartoe vooral de nijpende nood op Aruba leidde, was een verzoek aan de commandanten van Puerto Cabello en Coro om zooveel mogelijk uitvoer van mais toe te staan. Hierop werd gunstig beschikt, zelfs met opheffing van de uitgaande rechten, mits het uitgevoerde inderdaad voor eigen gebruik op de Curaçaosche eilanden bestemd was en niet weer van hier uitgevoerd zou worden.

Op den 7den April 1812 werd Venezuela geteisterd door een ernstige aardbeving, die duizenden slachtoffers eischte en vele steden en dorpen in puin legde. De gouverneur Hodgson vond hierin aanleiding om tegen den 17den een dankdag uit te schrijven, omdat Curaçao gespaard was gebleven. Voor het eiland had 
deze aardbeving nog het gevolg, dat zich hier vestigde de Schot William Lee met hetgeen hij van zijn drukkerij uit Caracas had weten te redden. Het eerste drukwerk, dat op het eiland verscheen kwam van zijn pers: het was The Curaçao Gazette and Commercial Advertiser, waarvan 11 December 1812 het eerste nummer het licht zag. Als The Curaçao Gazette kreeg het later naast den Engelschen een Nederlandschen tekst ${ }^{1}$ ).

Toen het bleek, dat er valsch papieren of kaartengeld in omloop was, besloot de raad van Politie met ingang op 10 Augustus 1812 al het kaartengeld in te trekken en daarvoor nieuw papieren geld uit te geven. Dit nieuwe geld was gestempeld met het Engelsche koninklijke wapen en had een waarde aanduiding (, ,agt realen", ,,een reaal") in het Hollandsch. Echter werd ook dit geld weer nagemaakt. In 1814 kwamen er naast de ,guillotines" van in vieren gekapte pilaardaalders, welke waarde van 18 op 21 stuivers werd verhoogd, vijfde deelen van dezelfde munt tegen 18 stuivers in omloop.

Het eerste gevolg van den oorlog tusschen Engeland en de Vereenigde Staten van Noord-Amerika was het verbod van uitklaring van schepen naar havens van den vijand en het embargo, dat op vijandelijke schepen in Engelsche havens werd gelegd.

Nog twee belangrijke maatregelen nam de gouverneur Hodgson in 1812. Op een Zondagmorgen, den 22sten November, had hij op zijn verblijf Penn een bezoek gekregen van 23 slaven van C. Ringeling, die zich ernstig beklaagden over de wreede behandeling, die zij van hun meester hadden ondergaan. Met watapana en het mes zouden zij gruwelijk mishandeld zijn en zij weigerden naar hun meester terug te gaan, omdat zij zich dan aan levensgevaar zouden blootstellen. De gouverneur bracht de zaak in den raad en deelde daar mee, dat hij de zaak onderzocht had en ook sporen van de beweerde mishandelingen aan het lichaam der klagers gevonden had. Ringeling werd voor den raad geroepen en verklaarde daar, dat de slaven geweigerd hadden te werken. Hij kreeg een boete van 500 pesos en een vermaning, terwijl de slaven werden aangemaand rustig het werk te hervatten. Kort daarna verscheen er een publicatie over de behandeling der slaven in het algemeen. Uitdrukkelijk werden daarbij werktijden vastgesteld van zonsopgang tot 11 uur en van 1 uur tot zons-

1) In 1816 stelde gouverneur-generaal Kikkert William Lee aan als 's konings drukker op een belooning van 750 pesos 's jaars. In $D e$ Curaçaosche Courant verschenen voortaan alle gouvernementsberichten. Lee stierf 8 Augustus 1823 op 37-jarigen leeftijd. 
ondergang. Op zondagen en andere heilige dagen zou niet mogen gewerkt worden. Voor noodzakelijken arbeid waren in beide gevallen afwijkingen van deze regels toegestaan. Het voedsel werd vastgesteld: voor mannen op 6 en voor vrouwen op 5 kan mais 's weeks van 1 October tot 31 Maart, en van 1 April tot 30 September op 5 en $4 \mathrm{kan}$. Verboden werd de slaven voor zichzelf te laten werken in plaats van hun het weekrantsoen uit te reiken, daar dit luiheid en roof ten gevolge had. Eveneens werd verboden in winkels op de plantages rum, suiker en tabak aan de slaven te verkoopen in verrekening met het rantsoen. De eigenaars hadden er voor te zorgen, dat hun slaven en slavinnen behoorlijk van kleeren waren voorzien. Straffen mochten niet op onredelijke wijze worden toegepast, en bij ernstige feiten moest aan den landdrost daarvan mededeeling worden gedaan. Het was niet toegelaten een groep slaven te straffen voor hetgeen een enkeling had misdaan. Bij overtreding van deze voorschriften zou de eigenaar een boete van 50 pesos verbeuren voor elk geval.

Het verval van den handel had, naar de gouverneur den raad van Politie meedeelde, tengevolge dat de uitgaven de inkomsten belangrijk overtroffen. Naar nieuwe middelen moest worden gezocht, en men vond die in een heffing van den 40sten penning voor geldleeningen op onderpand van onroerend goed.

Een nieuwe versterking van de verdediging van het eiland zocht de gouverneur het volgend jaar in de vorming van drie compagnieën burger-artillerie, waartoe alle blanken, vrije negers en vrije kleurlingen tusschen 15 en 50 jaar werden opgeroepen. De belangstelling schijnt niet groot geweest te zijn, want, toen de tijd voor aanmelding verstreken was, moest de oproeping herhaald worden met de bedreiging van hen, die zich niet zouden aanmelden, met verbanning, als ,,dit Gouvernement vijandelijk zijnde”.

De beperkende bepalingen, die voor de scheepvaart op de Engelsche koloniën golden, kwamen telkens weer in botsing met de belangen van de voedselvoorziening. Zelfs de gouverneur kende de grenzen zijner bevoegdheid niet, zooals bleek, toen hij in strijd met 's Konings bevelen den bekenden Joseph Foulke den invoer had toegestaan van beef, pork en butter van St. Bartholomeus. De raad besloot ' $t$ maar goed te vinden, omdat Foulke er zoo veel moeite en kosten aan gehad had.

Aan kasgeld bleef groote behoefte ontstaan. In den loop van 1813 werd van de weeskamer 12000 stukken van achten tegen $5 \%$ rente opgenomen. Hiermee waren de geldelijke moeilijkheden op den duur niet opgelost. Een plan van het raadslid Duyckinck om 
heel wat bezuinigingen in te voeren, o.a. door afschaffing van de kantoren van den boekhouder-generaal en den inspecteur-generaal der wegen, schijnt weinig bijval bij den gouverneur gevonden te hebben. Dan maar weer een nieuwe belasting uitgedacht, en gevonden in een heffing van 6 stukken van achten bij verkoop van een slaaf.

1814 was wel een zeer droevig jaar voor de kolonie. Dat den 11 den Maart kon worden afgekondigd, dat de oude betrekkingen van vrede en vriendschap tusschen Zijne Majesteit en de Provintiën der Vereenigde Nederlanden waren hersteld, veranderde niets. Alsof er niets gebeurd was, vertrok in September Hodgson naar Engeland, het bestuur overdragende aan den hoogsten commandeerenden officier John Lecouteur als luitenant-gouverneur. En van eenige belangstelling voor een herstelling van den band met het oude moederland, bleek niets. De nood was dan ook wel hoog geklommen, en Lecouteur kende de oude zorgen van zijn voorgangers. Kort na zijn optreden kwam er bij den raad een verzoekschrift in van een groot aantal inwoners over de levensmiddelenvoorziening. Aan ,,alle soorten van mond-behoeften, die men gewoon is tot brood te gebruiken" was gebrek. De droogte was groot en de oogsten waren gering. Openlijk werd het uitgesproken, ook door gouverneur en raden, dat hongersnood voor de deur stond. Mais werd verkocht tegen 5 pattinjes per schepel en 1 vat meel voor 40 pattinjes. De sterfte onder het vee was groot, en door gebrek aan voldoende voeding waren de slaven niet in staat het land te bewerken. Er werden twee maatregelen genomen. De eene was, dat de lading van het eerste schip met mais, dat mocht binnenkomen door het gouvernement zou gekocht en verkocht worden. Van wijder strekking was, dat voor zes maanden vrije invoer werd toegestaan van meel, maismeel, boonen, erwten, rijst en mais in Engelsche en neutrale schepen ,,van eenig land van vriendschap". Daarbij werd ,,uit hoofde der moeylijkheid, welke men thans ondervind in het invorderen der voldoening aan geld van zodanige ingevoerde artikelen" de uitvoer van cabrietenvellen en van Coro-hout toegestaan. Schepen beneden 15 ton, die de begeerde waar zouden binnenbrengen, werden vrijgesteld van inklaringsgelden.

Het is April 1815, nadat de afkondiging van de vrede tusschen Engeland en Amerika al eenige maanden tevoren is bekend gemaakt, als er zich iets voordoet, dat erop schijnt te wijzen, dat men genoeg van het Engelsch bestuur had. Negers en kleurlingen houden een optocht naar den berg Altena en voeren met zich 
poppen, die Engelsche officieren in uniform moeten voorstellen, met de bedoeling die daar te gaan begraven. Er kwam een publicatie van gouverneur en raden, waarin gesproken werd van verstoring van de algemeene rust en vrede en ernstige straf bij herhaling bedreigd werd. De politie werd versterkt met niet minder dan 24 man.

Nog bijna een jaar zou het duren, vóór de herstelling van het Nederlandsch gezag plaats vond. Wel kwam reeds einde Januari 1816 de vloot, voor dit doel uitgezonden, de St. Annabaai binnen, maar de Engelsche gouverneur wist nog van niets, en,, toen hij iets wist, bleek er nog van alles te regelen. Deze moeilijkheden en de geschiedenis van de feitelijke overdracht op 4 Maart 1816 van het gezag vindt men aan de hand der officieele stukken beschreven in het Tijdschrift voor Geschiedenis, land- en volkenkunde van 1914, waarheen ik moge verwijzen. W. M. Hoyer heeft in De WestIndische Gids (16den jg. 1934/5 blz. 219) meegedeeld het adres van hulde, dat de Curaçaosche leden van den Raad van politie (Beutner, Cancryn, Duyckinck en Van Uytrecht) den vertrekkenden Engelschen gouverneur aanboden, en diens antwoord.

Amsterdam 8 October 1943. 